\title{
Micronucleus assay in formalin exposed individuals
}

\author{
N. Pratheepa Sivasankari ${ }^{1, *}$, S. Sundarapandian ${ }^{2}$, E Sakthivel $^{3}$ \\ ${ }^{\mathbf{1}}$ Associate Professor, ${ }^{2}$ Professor, Dept. of Anatomy, ${ }^{\mathbf{3}}$ Assistant Professor, Dept. of Community Medicine, SRM \\ Medical College Hospital \& Research Centre, SRM University, Tamil Nadu, India
}

*Corresponding Author:

E mail: drpratheepa88@gmail.com

\begin{abstract}
Introduction: The aim of the study was to find out the nuclear abnormalities like Micronuclei in the oral mucosa of the formalin exposed individuals in the department of anatomy. This MN Aaasy is an inexpensive method. Materials and Methods: Faculties and staffs working in the department of anatomy and the first-year students were included in this study. Study sample consists of 50 subjects and was divided into 5 groups according the years of exposure. By scraping with the wooden spatula in the buccal mucosa Oral squamous cells were collected and smeared on the slides. The smeared slides were fixed with methanol glutaraldehyde fixative and stained with giemsa, maygrunwald stain. After airdrying 1000 cells were screened for Micronucleus (MN).

Results: Micronuclei frequency was more in the group who had more than 15 years of formalin exposure. The mean MN count was 9.60 and it was statistically significant when compared to other groups.

Conclusion: Micronucleus Assay is the most simple, feasible, inexpensive method to find out the nuclear abnormalities at an early stage in the formalin exposed individuals.
\end{abstract}

Keywords: Formalin, Buccal Mucosa, Micronucleus.

Received: $01^{\text {st }}$ August, 2017

Accepted: $31^{\text {st }}$ October, 2017

\section{Introduction}

India is likely to have 17.3 lakh new cases of cancer by 2020 with cancers of breast, lung and cervix. ${ }^{1}$ The national cancer institute included formaldehyde as a carcinogen. ${ }^{2}$ Formalin is a dissolved gas of Formaldehyde in concentrations from $37 \%$ to $54 \%$. Formalin is used in embalming processes as a disinfectant and preservative. Occupational exposure for formaldehyde is $1 \mathrm{ppm} 8$-hour time-weighted average (TWA) and $2 \mathrm{ppm}$ for short-term exposure limit (STEL). The recommended exposure standards provide adequate protection and protection against cancer. ${ }^{3}$

The genotoxicity of formaldehyde is due to the formation of DNA-protein cross-links. ${ }^{4}$ International organizations formed the guidelines for the safety assessment of chemicals. The micronucleus test the most feasible, reliable assay to assess the induction of nuclear abnormalities and useful in identifying the occupational exposure hazards and risk assessment. ${ }^{5}$

MN contain chromosome breaks lacking centromeres (acentric fragments) or whole chromosomes that are unable to join to the spindle poles during mitosis. MN is smaller than the main nuclei, hence the term "Micronucleus" (Fig 1). Micronucleus Assay is to find out the chromosome breakage and chromosome loss. ${ }^{6}$

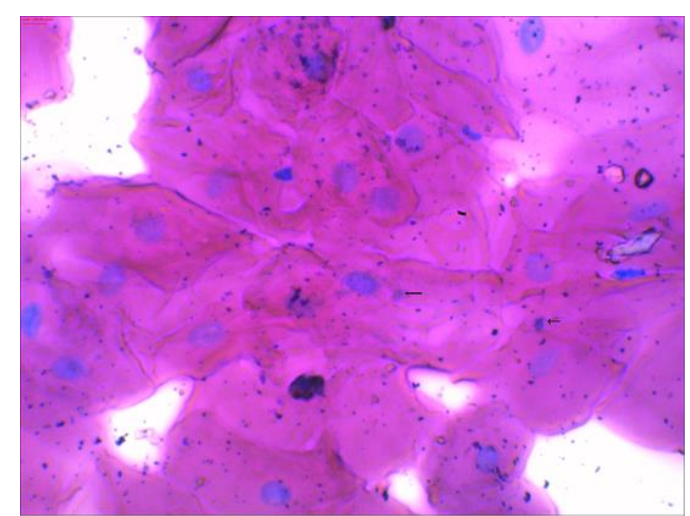

Fig. 1: Arrow shows Micronucleus

The aim of the study was the study to identify the occurrence of Micronuclei (MN) in individuals with different duration of formalin exposure.

\section{Materials and Methods}

Materials: Methanol, Glacial acetic acid, Giemsa stain and maygrunwald stain.

Inclusion criteria: Faculties and staffs working in the department of anatomy and the first-year students

Study sample consists of 50 subjects and was divided into 5 groups as follows

Group 1: less than 1 year of formalin exposure

Group 2: 1 - 5year of formalin exposure

Group 3: 6-10 years of formalin exposure 
Group 4: 10 - 15 years of formalin Group 5: more than 15 years of formalin exposure

Exclusion criteria: Alcoholics, smokers, premalignant cases and malignant cases.

Methods: Informed consent was obtained from the individuals. They were asked to rinse the mouth and with a clean wooden spatula the material was collected from the oral cavity by scraping the buccal mucosa. Scrapped material was spreaded on cleaned slides and smeared. After air drying, the slides were kept in the methanol glacial acetic acid fixative in the proportion 3:1 for 20 minutes. There slides were stained with May Grunwald and Giemsa stain. They were observed for MN under Bright Field Nikon microscope under 10 x 100 magnifications. (Fig 1) 1000 cells were screened in each person from the slides prepared.
Observations were recorded and tabulated. The frequency of $\mathrm{MN}$ was recorded and the collected data was subjected to anova. ${ }^{7}$

\section{Results and Discussion}

One-way anova was used to compare the micronucleus frequency and the period of exposure. Table I showed that the micronucleus frequency was more in the group who had the exposure for more than 15 years and mean $\mathrm{MN}$ frequency was 9.60. The MN Frequency was low in the individuals had less than one year of exposure and the MN Frequency was 0.80. Table II showed that the MN frequency within groups and between groups were also statistically significant. Fig 2 the bar diagram shows the mean MN Frequency and the duration of exposure to formalin.

Table I: One-way Anova: Comparison between duration of exposure and MN Frequency Descriptive

\begin{tabular}{|l|c|c|c|c|c|c|c|}
\hline $\begin{array}{l}\text { Years of } \\
\text { exposure }\end{array}$ & $\mathbf{N}$ & $\begin{array}{l}\text { Mean } \\
(\mathbf{M N})\end{array}$ & \multirow{2}{*}{$\begin{array}{c}\text { Std } \\
\text { deviation }\end{array}$} & Std error & \multicolumn{2}{|c|}{$\begin{array}{c}\mathbf{9 5 \%} \text { confidence interval for } \\
\text { mean }\end{array}$} & \multirow{2}{*}{ Minimum } \\
\cline { 6 - 7 } & & & & & Lower bound & Upper bound & \\
\hline$<1$ & 10 & 0.80 & .789 & .249 & .24 & 1.36 & 0 \\
\hline $1-5$ & 10 & 1.10 & .568 & .180 & .69 & 1.51 & 0 \\
\hline $6-10$ & 10 & 1.10 & .738 & .233 & .57 & 1.63 & 0 \\
\hline $10-15$ & 10 & 1.70 & 1.252 & .396 & .80 & 2.60 & 0 \\
\hline$>15$ & 10 & 9.60 & 6.222 & 1.968 & 5.15 & 14.05 & 2 \\
\hline TOTAL & 50 & 2.86 & 4.399 & .622 & 1.61 & 4.11 & 0 \\
\hline
\end{tabular}

Table II: Anova: comparison between the groups and within the groups

\begin{tabular}{|l|c|c|c|c|c|}
\hline \multicolumn{1}{|c|}{ Micronucleus } & Sum of squares & $\begin{array}{c}\text { Degree of } \\
\text { freedom }\end{array}$ & $\begin{array}{c}\text { Mean } \\
\text { square }\end{array}$ & F value & P value \\
\hline Between groups & 572.120 & 4 & 143.030 & 17.123 & 0.00 \\
\hline Within groups & 375.900 & 45 & 8.353 & & \\
\hline Total & 948.020 & 49 & & & \\
\hline
\end{tabular}

Mean of Micronucleus

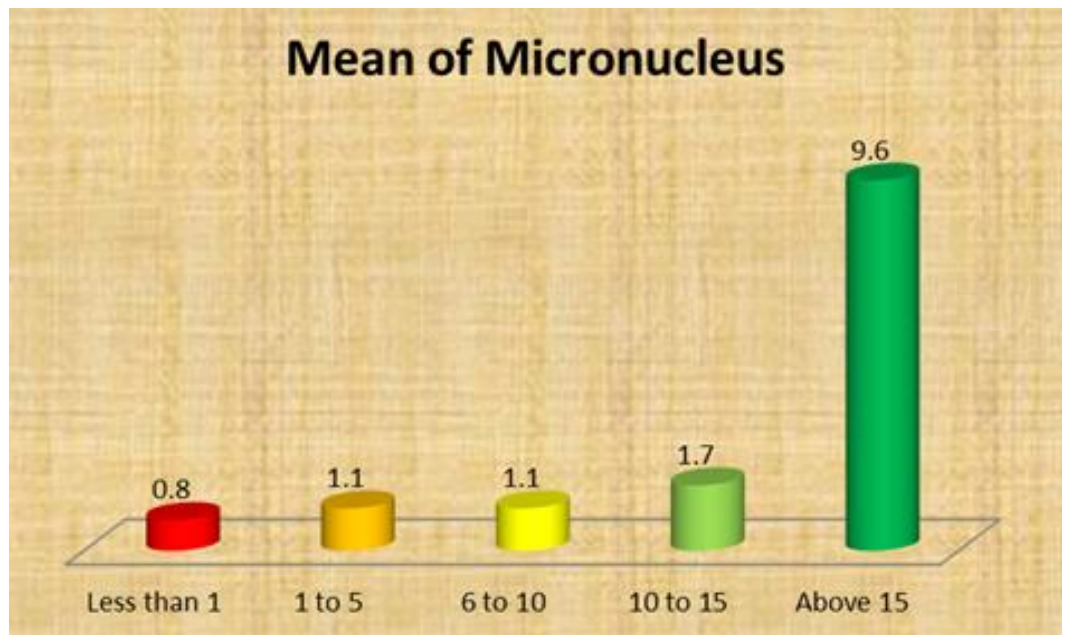

Fig. 2: Micronucleus mean in different groups, the maximam mean was seen in the last group which had > 15 years of exposure 
International agency for research on cancer said that a high mortality rate was observed among the formaldehyde-exposed workers had a statistically significant high mortality rate for nasopharyngeal cancer in comparison with unexposed population (SMR, 2.10; 95\% CI, 1.05-4.21) (p trend < 0.001). ${ }^{8}$ Our results were also well in correlation with the results of IARC. Increased MN Frequency in the neonates observed who exposed to the environmental pollutions by Michelle mergener, strengthens the report of our study that showed increased $\mathrm{MN}$ frequency caused by the the most important environmental pollutant formalin. ${ }^{9}$ The increased MN frequency was noticed in all exposure groups when compared with their control groups depends upon the dose and duration of the exposure $(\mathrm{P}<0.05) .{ }^{10}$ Shekawat, in his study proved the same as a significant increase in the MN frequency was found between duration of exposure to formaldehyde (year of exposure) and frequency of micronuclei in the epithelial cells $(<0.05) .{ }^{12}$ It was well correlated with the results of our study which showed increased $\mathrm{MN}$ Frequency in the individuals who had more than 10 years of formalin exposure

Sasane et al., in their study, both in peripheral blood lymphocytes $(p<0.001)$ and in epithelial buccal cells $(p<0.001)$ the $\mathrm{MN}$ frequency was high in occupationally exposed workers than in the control group ${ }^{11}$ concluded that inhalation through oral and nasal cavity damage the oral and nasal mucosa respectively.

This showed that, exposure duration also had some relevance with the development of health issues. In contrast to this discussion, Bonetti et al reported that no appreciable risk for oral cancer in industry workers and professionals exposed to formaldehyde and the increased MN frequency was due to other risk factors. ${ }^{13}$ In our study exclusion and inclusion criteria were properly designed so this could not have happened in our study.

Statistically significant MN count was seen in older age. ${ }^{14}$ Increase in the MN frequency in the group had more than 15 years of exposure might be due to the aging criteria. Most of the individuals in the last group were above 50 years of age (technicians and professors). So, we concluded that prolonged exposure to formalin was directly related to the increase in the $\mathrm{MN}$ Frequency. The dissection hall attenders and pathology laboratory attenders are coming under the prolonged exposure category and faculties working for more years in the department of anatomy also expose to formalin for longer duration and hence the duration of exposure to be minimized.

\section{Conclusion}

Mean MN frequency was more in the group who had more than 15 years of exposure to formalin. The mean MN frequency within the groups and in-between the groups were statistically significant and hence the exposure to the formalin in the dissection hall to be minimized. Yearly once, the workers need to be investigated for MN frequency and hence we can diagnose the genotoxicity at an early stage.

\section{References}

1. Over 17 lakh new cancer cases in India by 2020: ICMR;May, 2016. Available from http://www.midday.com/articles/over17lakhnewcancercasesinindiaby $2020 \mathrm{icmr} / 17248152$

2. 14th Report on Carcinogens (RoC) - National Toxicology Program - NIH;May, 2017. Available from http://ntp.niehs.nih.gov/go/roc

3. Formaldehyde in embalming - NICNAS; December, 2006. Available from https://www.nicnas.gov.au/chemicalinformation/factsheets/chemicalname/formaldehyde-in-embalming

4. Szende, B., Tyihák, E, "Effect of formaldehyde on cell proliferation and death" Cell Biology International (2010) 34,1273-82.

5. Makoto Hayashi "The micronucleus testmost widely used in vivo genotoxicity test" Genes Environ(2016) 38,18.

6. Fenech $\mathrm{M}$, "The in vitro micronucleus technique "Mutation Research (2000)455,8195.

7. Nersesyan A, kundi M , Atefie K, Schultehermann R, Knasmuller S ,"effect of staining procedures on the results of micronucleus assays with exfoliated oral mucosal cells" Cancer Epidemiol Biomarkers Prev(2006)15(10)1835-40.

8. Studies of cancer in Humans. IARC Monographs on the Evaluation of Carcinogenic Risks to Humans; 2006.88.Available from http://monographs.iarc.fr/ENG/Monographs/vo 1110/index.php

9. Michelle Mergener, Cláudia R. Rhoden, Sergio L. Amantéa , "Nuclear abnormalities in cells from nasal epithelium: a promising assay to evaluate DNA damage related to air pollution in infants" J Pediatr. (Rio J)(2014)90(6),632-6

10. L, Ramazan Mert, A.caglan Karasu Benli, GonulArslan, "Determination of histological and genotoxic effects of formalin on Nile tilapia Oreochromis niloticus " Aquaculture research(2014)1-10

11. Susana Viegas, Carla Nunes, Joana MaltaVacas, Mário Gomes,Miguel Brito, Paula Mendonça ,João Prista ,"Genotoxic effects in occupational exposure to formaldehyde: A study in anatomy and pathology laboratories and formaldehyde-resins production" J Occup Med Toxicol (2010)5,25

12. Shekhawat S, Jadon VS, Garg R, Mogra $\mathrm{K}$,"Cytogenetic Effects of Exposure to 
Formalin Vapours in Buccal and Nasal

Mucosae: A Study in the Students of Anatomy and Embalmers" Adv Med Dent Res

(2015)1(1),1-5.

13. C. Bosetti, J. K. McLaughlin, R. E. Tarone, E.

Pira, C. La Vecchia," Formaldehyde and cancer risk: a quantitative review of cohort studies through 2006" Annals of Oncology (2008)19,29-43.

14. Gregory Alves Ferraz, Antônio de Oliveira Costa Neto, Eneida de Moraes Marcílio Cerqueira, José Roberto Cardoso Meireles, "Effects of age on the frequency of micronuclei and degenerative nuclear abnormalities" Rev. Bras. Geriatr. gerontol, Rio De Janeiro"(2016)19(4),627-34. 